\title{
Despojos da guerra, rastros de identidade:Alguns dilemas da literatura africana de expressão portuguesa pela voz de Tiara
}

\section{Despoilments of war, traces of identity: dilemmas of the African Literature of Portuguese Expression through Tiara's voice}

\author{
Naira de Almeida Nascimento ${ }^{1}$ \\ Universidade Tecnológica Federal do Paraná
}

Resumo: É objetivo do estudo refletir sobre alguns aspectos da recepção da literatura africana de expressão portuguesa, em especial no Brasil, e sobre algumas das suas condições da produção literária nos respectivos países, tendo como ponto de partida a representação da diáspora africana no romance Tiara (1999), da angolana naturalizada guineense Filomena Embaló. O artigo divide-se em três partes. A primeira contempla a análise do romance, pontuando a construção do enredo e de alguns personagens; a segunda investiga a inserção desse título na produção africana de língua portuguesa e tece considerações a respeito do mercado editorial nos principais centros urbanos lusófonos na África; enquanto a terceira parte levanta algumas hipóteses interpretativas para as variantes recepcionais, a partir de uma breve incursão pela produção romanesca dos dois autores em maior evidência no mercado editorial brasileiro: Mia Couto e José Eduardo Agualusa.

Palavras-Chave: Literaturas africanas em língua portuguesa. Filomena Embaló. Mia Couto. José Eduardo Agualusa.

\begin{abstract}
The purpose of this study is to reflect upon some aspects of the African literature of Portuguese expression, especially within the Brazilian context, and also about some of its production means in both countries. The starting point is the African diaspora representation in the novel Tiara (1999) written by Filomena Embaló, an Angolan, naturalized Guinean writer. The article is divided into three parts: the first one analysis the novel, highlighting plot structure and some of its characters. The second part investigates the title insertion within the Portuguese African production and makes considerations about the editorial market in Portuguese language urban centers in Africa. Finally, the third part presents some interpretative hypothesis to the receptional variants, through a brief incursion in the Romanesque production from two of the most important authors in the Brazilian editorial market: Mia Couto and José Eduardo Agualusa.
\end{abstract}

Keywords: Portuguese African Literature. Filomena Embaló. Mia Couto. José Eduardo Agualusa.
${ }^{1}$ Doutora em Estudos Literários (UFPR).E-mail: naira.alm@gmail.com 
Despojos da guerra, rastros de identidade: Alguns dilemas da literatura africana de expressão ...

\section{A África pela voz de Tiara}

Há uma África que sonhamos, uníssona, composta por savanas e misérias, onde o sol atinge matizes surpreendentes e onde populações morrem à míngua, no descaso público, acossadas pela fome e pelas guerras. E provavelmente existem muitas outras Áfricas, que bem poderiam passar sem os atributos mencionados; atributos que, diga-se de passagem, não destoam tanto da nossa realidade brasileira.

A excelência do romance Tiara, da angolana naturalizada guineense Filomena Embaló, está justamente em proporcionar ao leitor pouco afeito à geografia africana as percepções de algumas Áfricas do imenso continente. Publicado em 1999, o romance mereceu edição por parte do Instituto Camões, sob a chancela Coleção Lusófona.

A autora, radicada em Paris, onde atua na organização intergovernamental União Latina, constrói uma narrativa com fortes pontos de contato com sua história de vida, apesar de o texto renunciar à aproximação dos referentes externos quando sugere nomes imaginários para países, localidades e movimentos políticos que participam do enredo.

A protagonista, Tiara Riba, nascida em Porto Belo, país situado na costa ocidental africana, é levada ao exílio, juntamente com sua família, em razão do início da guerra civil, quando contava com 18 anos. Funcionário da administração portuguesa, o pai vê o círculo fechar-se sobre aqueles que, no período anterior à independência, mantinham cargos nos quadros do regime colonial. A mãe, natural das Ilhas Caim, apesar de ter construído sua vida em Porto Belo após o casamento, legou aos filhos as tradições e costumes de seu país.

Por aí já se insinua o multiculturalismo que domina em Tiara. Também o enredo sugere a aproximação entre as memórias de Filomena Embaló, filha de pais cabo-verdianos, que, assim como na ficção, se viu afastada da pátria angolana em 1975, em decorrência dos desdobramentos da independência política do país. Tiara registra a partida caótica:

O sol já ia alto quando o pequeno Fiat terminava a última viagem para o aeroporto. Foram precisas três voltas para transportar os catorze sacos de bagagem e a família toda. Os sacos tinham a particularidade de terem sido confeccionados em casa. Na debandada dos refugiados, fugidos e precavidos, que partiam aos milhares, as malas esgotaram-se no mercado e os últimos decididos a partir tiveram que improvisar o invólucro das suas bagagens.

O aeroporto estava apinhado de gente. Uns gritavam para se fazerem ouvir pelos parentes que se encontravam na outra extremidade da sala de embarque. Outros choravam baixinho a terra que deixavam e os sonhos que enterravam. Havia quem jubilasse ao reencontrar um ente querido, perdido na fuga que a guerra civil precipitara. (EMBALÓ, 1999, p. 9). 
Em contraponto ao futuro imprevisto, a família vê-se obrigada a abandonar o seu pequeno jardim, erguido na certeza da sua solidez e da sua longevidade, episódio que acometeu também muitos dos retornados portugueses:

A família, numerosa, vivia em Vila Boa, capital de Porto Belo, numa grande mansão de estilo colonial, na parte mais alta da cidade. A casa fora construída pelo bisavô do pai de Tiara, havia já quase um século. Testemunhavam isso as enormes colunas que circundavam a casa, bem como as altas janelas e portas que deixavam penetrar uma agradável brisa marítima, nos dias quentes do mês de Março. O mar ficava a umas duas dezenas de metros mais abaixo, no sopé do morro onde estava erguida a mansão familiar. (EMBALÓ, 1999, p. 11).

Resistente em aceitar as imposições do destino, Tiara retornaria muitos anos depois ao antigo país, a passeio, sem conseguir reconhecer nele as sombras da sua meninice, tamanha a degradação que vê nas ruas e casas de sua memória.

O destino da família Riba, Terra Branca, guarda com o país de origem a mesma língua, mas dele se afasta não só pelo clima frio como pela barreira cultural. A metáfora óbvia ao continente europeu, terra de brancos, remete assim a outro encalço da diáspora africana. O segregacionismo na nova terra é mediado com cautela pela narrativa, mais sugerido que desenvolvido. No entanto, é justamente pelo que cala que o assunto mostra-se mais sutilmente na sua interdição. A disposição clara de não alimentar um discurso rancoroso contra o antigo colonizador e até uma certa condescendência com uma parcela de discursos paternalistas em relação à história africana força a ficção a silenciar situações de hostilidade e segregação cultural e racial vividas diariamente por estudantes e trabalhadores negros nos domínios da Terra Branca.

No romance, a justificativa vem pela questão revolucionária. Tiara torna-se amiga de um grupo de estudantes do Muriti, pequeno país africano ainda em vias de se tornar independente. Solidária para com aquela luta política, ela vai dominar rapidamente o idioma falado por eles enquanto prepara o engajamento que decidirá sua vida naquele país. Nesse sentido, a opção pelo topônimo Terra Branca não funciona apenas para tornar a situação colonial alegórica e extensiva à prática do neocolonialismo que dominou os países europeus, mas também como estratégia para dissimular uma crítica direta, que possa gerar constrangimentos mútuos, aspecto em suspensão no texto:

Na nova cidade, Tiara sentia-se perdida. Os habitantes eram pouco acolhedores, muito distantes e sempre apressados. Surpreendia-a o facto das pessoas passarem umas pelas outras e não se cumprimentarem. Em Porto Belo seria impensável e sinônimo de uma grande falta de educação! (EMBALÓ, 1999, p. 20). 
Despojos da guerra, rastros de identidade: Alguns dilemas da literatura africana de expressão ...

Ou ainda:

Tinha notado que, naquele país, o humor das pessoas variava em função do tempo que fazia. Aos dias cinzentos e chuvosos, correspondiam humores tristes e azedos. Inversamente, quando havia sol, era o entusiasmo que predominava. Sendo o sol uma coisa rara na Terra Branca, compreendia por que razão, a maior parte do tempo, as pessoas andavam mal encaradas. (EMBALÓ, 1999, p. 58).

Na Terra Branca, Tiara ingressa no curso de História e, distinguindose como excelente aluna, completa uma segunda licenciatura, em Direito. Enquanto isso, sua vida amorosa é decidida através do casamento com um líder revolucionário muritiano, Kenum Savo. Aproximando-se das memórias pessoais da autora, que adotou a Guiné-Bissau, Tiara, já formada, acompanha o marido na nova vida no Muiriti. A Frente Norte, facção da Frente de Libertação do Muriti, ocupa um território periférico, o Guessa, onde Tiara depara-se com uma vida de imensas privações, comum àquela população. Sem água canalizada nem luz elétrica, as condições de vida e de higiene mostram-se precárias. Também o sustento de cada dia deve ser preparado desde sua origem, via de regra, pela mulher:

Era dura a vida no campo. Era preciso pilar os alimentos duas vezes por dia! Todo o trabalho doméstico era um empreendimento que exigia um esforço físico. Os eletrodomésticos eram ainda um luxo para a maior parte das mulheres do mundo que, tal como Zada, deveriam arrancar dos seus braços a energia que fazia girar a economia doméstica. (EMBALÓ, 1999, p. 161).

Um dos aspectos mais destacáveis no livro é justamente o de oferecer uma perspectiva mais heterogênea acerca das culturas africanas. Existe um impulso de criarmos generalizações a partir da concepção de África. Tiara demonstra que, mesmo sendo africana, a realidade do Muiriti em nada se identifica com aquela da terra natal. O que nos evoca Stuart Hall (HALL, 2009) quando conclui que toda identidade é relacional: depende do prisma em que é tomada. Ou seja, no território da Terra Branca, os nativos de Porto Belo e do Muriti criam identidades frente às diferenças locais, mas, quando estes dois países são confrontados, cada identidade tende a se diluir, o que coloca em causa a noção de um pan-africanismo: "Do ponto de vista cultural, Tiara sentia-se próxima dos muritianos. Provenientes do mesmo continente, compartilhavam os mesmos valores fundamentais, apesar das particularidades culturais próprias a cada povo e de professarem religiões diferentes.” (EMBALÓ, 1999, p. 22). Até mesmo o período de convivência com os muritianos na Terra Branca serve pouco como medida para a realidade que Tiara encontra no interior do país, em parte por se tratar de uma elite de estudantes que já se distanciou das tradições milenares que vigoram no interior do país. 
A alegorização dos nomes pátrios atende ainda a uma outra função na narrativa: criar um deslocamento temporal entre os dois países, Porto Belo e Muriti. No plano historiográfico, Guiné-Bissau é a primeira colônia portuguesa a conquistar a independência, portanto anterior à de Angola, em 1975, mas, no romance, enquanto o Muriti ainda vive a luta separatista, Porto Belo já alcançou a sua autonomia política desde há décadas. O anacronismo ficcional permite que os desdobramentos e as desilusões do período pós-independência já sejam vivenciados em Porto Belo, ao passo que o Muriti representa ainda as utopias revolucionárias. As diferenças entre os processos históricos de ambos os países são acentuadas para justificar o engajamento de Tiara, já descrente dos progressos políticos em sua terra natal:

Olha o meu país, Porto Belo! Independente há apenas trinta anos e já mergulhado numa guerra civil! É certo que as condições a que acedeu à independência, não foram idênticas às do Muriti. A nossa independência saiu de um processo de negociações com a antiga metrópole. Não houve grandes mudanças na forma de gerir o país. Apenas o assumir do poder por nacionais, saídos da classe privilegiada na época colonial, na altura, quase todos mestiços. (EMBALÓ, 1999, p. 40).

O final do trecho toca numa questão latente para a colonização angolana, que, na Guiné-Bissau, não atingiu grande expressão. Utilizados intensamente pelo poder colonial para ocupar os postos administrativos, os mestiços passam a ocupar um entrelugar desconfortável. Considerados angolanos de acordo com a perspectiva dos portugueses ou de seus descendentes, os mestiços, como no caso de Tiara, passam a ser objeto de perseguição para a maioria da população, essencialmente negra. No romance, lemos a alegação de Tiara de que o presidente de Porto Belo teria sido responsável em parte, por estimular a rejeição aos mestiços e contribuir para o seu afastamento dos postos de direção.

Já no Muriti/Guiné-Bissau, a situação caminhou de forma distinta, visto o número de mestiços ter sido sempre pouco significativo. Diferentemente de Porto Belo, a opção colonialista optou por rejeitar os casamentos mistos, evitando assim criar uma classe privilegiada: “... os filhos mestiços dos colonos, normalmente frutos de violações ou de ligações clandestinas, não eram reconhecidos pelos pais, e, por isso, nunca foram privilegiados em relação ao resto da população.” (EMBALÓ, 1999, p. 42).

Em parte por essas razões, a inserção de Tiara no mundo de Kendu não se dá tranquilamente. A família de Kendu não aceita a noiva visto que, tradicionalmente, o casamento é um assunto que cabe aos pais decidirem, sobretudo nesse caso que envolve o destino da descendência de um líder tribal. Kendu representa dois papéis que se antagonizam: o líder tradicional de seu povo e o chefe revolucionário, em contato com os valores modernos. 
Despojos da guerra, rastros de identidade: Alguns dilemas da literatura africana de expressão ...

Além de não pertencer ao universo do Senda, região ao sul do país, terra natal de Kendu, Tiara é ainda uma estrangeira no país, o que inviabiliza sua acolhida, sobretudo pela sogra.

Rompendo, a princípio, com a lógica patriarcal, o casal fixa residência à distância dos sogros, no Guesso, em território conquistado pela frente revolucionária, até o ano da independência do país, quando Kendu assume o cargo de Secretário de Estado da Educação no novo governo e eles passam a viver em Rani, a capital. Apesar de melhor estruturada que o resto do país, as marcas do regime colonial são ainda patentes:

Contrastando com as grandes capitais do continente, era uma cidade pacata. Dividia-se nitidamente em duas zonas: a cidade de ruas asfaltadas, bem urbanizada e cuidada, de casas todas caiadas de branco e onde viveram os colonos e a cidade das ruas de terra vermelha e de casas de zinco, onde moram os muritianos. Por si só, Rani transcrevia a sociedade segregacionista que imperava na colónia. As duas comunidades viviam lado a lado, só as unindo a necessidade de, uns, de mão de obra e, de outros, de emprego. (EMBALÓ, 1999, p. 183).

Não só o Senda exibe fortes códigos sociais. Tiara encontra no Muriti uma sociedade rigidamente hierarquizada em que o papel da mulher, apesar dos avanços da ação revolucionária, está inquestionavelmente delineado. Opondo-se à condição submissa feminina naquela região, Tiara envolvese no movimento de alfabetização das mulheres e, vazando um discurso que condena as práticas de mutilação feminina, acaba por indispor-se com parte da comunidade local.

Além das precárias condições estruturais que encontra, ela deve se adaptar também aos costumes locais. Até as mais simples expressões de afeto, como andar de mãos dadas com o marido, devem ser evitadas em público por constituírem sinal de exibicionismo da vida íntima.

A princípio, a vida do casal na capital supera parte desses problemas, mas a tal ansiada independência política cria outros obstáculos para a administração pública:

O Muriti carecia de quadros a todos os níveis. Os existentes eram os que vieram da diáspora e os que o movimento mandara formar durante a Luta. Os colonos que exerciam uma actividade económica partiram quase todos, levando tudo o que lhes fosse possível. Das pequenas unidades fabris existentes, apenas ficaram as paredes dos edifícios... O sistema de comercialização dos produtos agrícolas ficou abalado, pois era aos comerciantes da metrópole que os agricultores vendiam a sua produção. (EMBALÓ, 1999, p. 193).

O ímpeto revolucionário vai, contudo, amainando não só com as dificuldades mas também com as práticas de um poder corrompido, que 
utiliza a via estatal para cobrar rancores da época colonial ou então em benefício próprio. Apesar do engajamento na luta a favor da independência, sua condição de estrangeira é permanentemente lembrada e serve de argumento para não aceder a cargos na nova gestão, como ocorre no concurso a responsável pelo Centro de Estudos de História do Muriti, em que é preterida em favor de um dos quadros do movimento.

Depois de muitos anos de um casamento harmônico, sua vida pessoal também é abalada, sendo mais uma vez confrontada com os códigos culturais do país adotado. Numa das visitas de Kenum à família no interior, a mãe arma-lhe uma armadilha, obrigando-o a adotar uma segunda esposa, ou seja, a aceitar um casamento poligâmico, conforme as práticas tradicionais.

Durante algum tempo, Kenum mantém a dupla vida: uma esposa em Rani; outra, no Senda. Até que um problema de saúde com o filho gerado dessa nova relação força mãe e criança a procurarem o provedor na capital. É Tiara quem os recebe, descobrindo o segredo do marido e pondo fim ao casamento. Impedida de engravidar em razão de um ferimento sofrido durante os anos de guerra, Tiara, uma mulher estéril, é ainda mais repudiada pela família de Kenum; uma mulher sem descendência não tem serventia.

Os desgastes no trabalho como conselheira jurídica do Instituto Nacional de Desenvolvimento e o rompimento com Kenum deixam a vida em Rani sem perspectivas. Sente-se expatriada do país que adotou. Também já não vê qualquer traço de identidade com o país natal, Porto Belo, a não ser as lembranças do período pré-revolucionário. A Terra Branca, onde vivem seus pais e alguns irmãos, tampouco soube cativá-la. Decide então retornar para o interior do país, no Guesso, onde, nos anos de luta, sentiu-se realizada com o trabalho, com os amigos e com o povo, apesar de toda a carência material da região:

Tiara passou a noite em branco. Levou todo o tempo a organizar a sua vida futura. Nos dois meses que lhe restavam no Instituto, previu etapas. Iniciar o processo de divórcio, ir ao Guesso em prospecção. Precisava de arranjar uma casa e um pequeno jardim, onde pudesse cultivar alguns legumes. Tinha algumas economias que poderiam aguentar os primeiros tempos. Depois se veria. De qualquer forma, sobreviveria como a população, porque tencionava integrar-se completamente. (EMBALÓ, 1999, p. 245).

\section{Tiara entre as vozes de África}

O romance Tiara fala não só por aquilo que ele aborda, mas sobretudo pelo que falta a ele. O tom folhetinesco predomina, seja pela construção do enredo ou dos personagens. Tiara está longe de ser um personagem 
Despojos da guerra, rastros de identidade: Alguns dilemas da literatura africana de expressão ...

problemático, apesar das encruzilhadas que se interpõem no seu destino. Diríamos que Tiara é, por excelência, um protótipo do mais puro Romantismo. Forte, bela, inteligente, justa, divertida, solidária, abnegada, enfim, não se encontram defeitos nela, o que provoca até mesmo um certo constrangimento num romance que sinaliza para a forte presença do alter ego. A narração em terceira pessoa disfarça mal o recorte memorialístico.

O retrato da protagonista, que nunca vacila, nunca foi vil, ridícula, absurda ou que "quando a hora do soco surgiu" nunca se agachou "para fora da possibilidade do soco" (PESSOA, 1980, p. 268), contrasta vivamente com o herói da Modernidade, a ponto de torná-la irreal e a sua própria narrativa, desacreditada. Viveu à espera casta do verdadeiro amor, a ele submeteu sua vida, na luta, na privação, no confronto com os outros. Num gesto maternal, salva uma criança no bombardeio que a privaria da maternidade. Sua correção moral é tanta que não hesita em abandonar o homem que ama pelo delito de uma noite e pela mentira calada. Como que premiando tal caráter, o destino coloca a sua porta um antigo amor, ainda dos tempos de Porto Belo, já separado da esposa a quem se unira por um dever moral, o que ainda confere à narrativa um clima de happyend.

Enfim, visto desse prisma, Tiara mais merecia habitar o mundo das fadas e das heroínas do Romantismo, associação que não se mostra totalmente indébita. Ao ler Tiara, pensamos mesmo estar na presença de um romance de formação. Não apenas no sentido do Bildungsroman, mas também num sentido mais amplo, de uma literatura nacional em formação, nos termos emprestados a Antonio Candido.

Diferentemente de alguns países africanos de língua portuguesa, em que a expressão literária parece ter atingido sua maturidade, a produção guineense, em especial a de prosa, demonstra a tentativa de salto num contexto em que a literatura configura-se como objeto de rarefação. O nome de maior envergadura na prosa guineense, Abdulai Silá, assina uma obra que também se ressente de maior finalização. Ainda assim, seu esforço como escritor só foi perceptível graças à editora que ele mesmo criou e que publicou seus três romances: Eterna paixão (1994), A última tragédia (1995) e Mistida (1997), a Kusimon Editora. Engenheiro eletrotécnico, formado em Dresden, Alemanha, a atividade literária para Silá é subsidiária e dependente do exercício empresarial, exercida no ramo das telecomunicações e da informática, em Bissau.

Nos romances de Silá, como também em Tiara, revive-se o drama da política pós-colonial no país. Os poucos prosadores que se aventuram no campo literário repassam em suas narrativas as desilusões do pós-guerra. A proximidade a um ciclo ainda inconcluso e o envolvimento político dos autores fazem dessa literatura uma expressão ainda com um cariz fortemente testemunhal, em que o acontecimento histórico não conseguiu transplantar-se com maior plasticidade. Ainda cumpre exorcizar o passado 
recente enquanto o presente não aponta desdobramentos otimistas a curto prazo.

Para ficarmos apenas com o exemplo de um país próximo historicamente da Guiné-Bissau, o arquipélago de Cabo Verde, as diferenças frente à política educativa e editorial já são gritantes. Como destaca Filomena Embaló, enquanto que o primeiro estabelecimento de ensino secundário na Guiné só foi aberto em 1958, em Cabo Verde, o primeiro liceu data de 1860, registrando-se a responsabilidade do Estatuto do Indigenato pela exclusão de quase a totalidade da população até pelo menos o início da década de 1960. Já a Editora Nimbo, primeira editora pública guineense, só inicia suas atividades em 1987, sendo fechada pouco anos depois. (EMBALÓ, 2004).

A necessidade de se escrever uma história guineense subjaz claramente na própria ficção. Diante da carência de trabalhos específicos, a própria Filomena Embaló desdobra-se num duplo de historiadora ao assinar, juntamente com Hildo Honório do Couto, Literatura, Língua e Cultura na Guiné-Bissau, volume comemorativo da Revista Brasileira de Estudos Crioulos e Similares Papia (2010). Delega-se, dessa forma, a si mesma uma função semelhante à de embaixadora do país, valendo-se dos contatos e da posição que ocupa a partir do centro europeu.

A situação singular de Guiné-Bissau alerta-nos para a tendência a que quase nunca resistimos: a de amalgamar a história dos países africanos, sobretudo aqueles de língua portuguesa, como se eles compartilhassem não só a mesma história mas também a mesma cultura e, por extensão, a mesma literatura. Ao projetar uma personagem que traz uma história fundada na diversidade cultural, o romance Tiara possibilita a reflexão do elemento interno (África) a partir do alheio (Muriti), construindo uma perspectiva dupla sobre uma abordagem que tende à uniformidade. Consegue ainda criar, no nível narrativo, outras tensões: como aquela entre o colonizado e o colonizador, entre mestiços e negros, ou entre as próprias etnias de um mesmo país. Sinalizado pela própria dedicatória, Tiara contempla ainda outra discussão: o espaço da mulher na sociedade abordada. A submissão feminina diante do poder masculino, a prática dos casamentos poligâmicos ou a excisão clitoriana expressam por diferentes formas a quase invisibilidade das mulheres no plano literário, como autoras, ou a sua presença em termos muito mais restritos. Ou seja, a matéria romanesca conjuga-se às insuficiências da própria forma, ainda em gestação na literatura guineense.

Mesmo que as literaturas africanas construam-se talvez mais por diferenças que por semelhanças, a tentativa de homogenização insiste-se sobretudo no âmbito temático. Não é incomum associarmos as literaturas africanas aos assuntos bélicos, sejam eles relativos ao período colonial ou pós-colonial. Longe de surgir apenas como uma opção literária diante de uma história colonial que deixou traços semelhantes em seus territórios, essa recorrência parece dizer muito sobre as condições de produção 
e de publicação de seus escritores. Se, em muitos casos, a guerra ainda distingue-se como um tema candente nas literaturas africanas, ela se torna muito mais emblemática para uma indústria editorial, sedenta em oferecer ao mercado retratos estereotipados da realidade africana com doses de sensacionalismo.

Em parte, a evocação temática obedece a um impulso de uma literatura-testemunho, expressões de sociedades comovidas ainda pela história imediata, mas, por outro lado, ela parece servir como bilhete de entrada no mercado editorial, atento às demandas criadas por ele mesmo. A diáspora africana chega assim a um esgotamento temático que obriga inevitavelmente seus autores a um reinventar-se a partir das mesmas bases. $\mathrm{O}$ escritor se submete então a um duplo esforço: ele não deve apenas tematizar a guerra, mas deve ainda conseguir recriá-la poeticamente, tarefa plenamente realizada, por exemplo, em Terra sonâmbula, de Mia Couto.

Percurso semelhante percebe-se na inclusão da temática da magia. Se o continente africano é uma terra assolada por guerras e miséria, ela também se distingue pelo lugar que o mágico ocupa socialmente; terra em que o surreal não é mero construto linguístico, mas que emana naturalmente de seu povo. E não nos parece exagero supor que se trata de uma via compensatória, sob a ótica paternalista, a que também, mutatis mutandis, já estivemos sujeitos em vários momentos de nossa história. Queremos nos referir ao discurso que descreve um povo que, apesar das enormes adversidades, canta, dança e é feliz. Ou seja, o viés mágico da cultura conseguiria diluir a crise acarretada pelas guerras, pela miséria e pela incompetência política.

Diante de um mercado editorial que não se coíbe de impor sua pauta de trabalho, poderíamos questionar se existe espaço para romances africanos que não anunciam a temática pós-colonialista ou que não imprimam ao seu texto uma certa ambiência com contornos exóticos? Desse modo, parece instaurar-se um círculo em que o escritor está fadado a girar, pelo menos enquanto houver tal demanda.

Esse quadro um tanto perverso nos faz evocar a situação do romance de 30 no Brasil. Talvez não por puro acaso, essa produção funciona ainda como referência para escritores e leitores tanto em Portugal como nos países africanos de língua portuguesa. A resposta positiva a tal literatura no Brasil, à época, deve-se em parte a essa dupla perspectiva. Se o texto nos apresentava um mundo com que dividíamos traços em comum, ele também incluía uma realidade dominada por forças aparentemente estranhas, da qual são exemplo a seca e o coronelismo. Esse jogo de transformar o "mesmo" (o "homem pálido, magro de cabelo escorrendo nos olhos", o seringueiro do Mário de Andrade de "Descobrimento") em "outro" parecia criar um fascínio para a sociedade niveladora, centrada nos grandes centros urbanos do Sudeste. 
Não é necessário relatar as consequências desse processo que projetou culturalmente o Nordeste, ainda que às custas de sua estereotipia. Os retratos da seca e da miséria endêmica nunca mais abandonaram o imaginário acerca do Nordeste. Romper com esse ciclo foi a tarefa que coube de forma quase trágica a um escritor como Graciliano Ramos. Em Angústia, encontramos simultaneamente o relato, o questionamento e a tentativa de superar os determinismos das fronteiras físicas e culturais.

Num momento em que o próprio conceito de regionalismo tende a ruir diante das tensões da contemporaneidade, a demanda intrínseca pelo alheio parece mudar sua rota de destino e elege a África como o território do mundo desconhecido, revivendo os dramas neocoloniais, emblematicamente encenados por Joseph Conrad em O coração das trevas (1902), e acrescidos, no presente, dos dramas pós-independência.

Se a nova legislação educacional (lei 10.639, de 2003), que prevê a obrigatoriedade da história africana na cultura brasileira, estimula um impulso editorial nesse sentido, a política nacional em relação aos países africanos de língua portuguesa parece investir em duas frentes distintas, mas aliadas. A primeira, de cariz paternalista, ou na posição de primo rico, como já sugeriu Mia Couto, presta-se a uma espécie de assistencialismo, endossando um discurso corrente nos países ocidentais. É de se salientar próxima a essa vertente a tentativa de aproximação do último governo brasileiro (2002-2010).

A outra, não se distinguindo muito do interesse do capital estrangeiro internacional em África, luta por fatias dos mercados nacionais. Para se restringir ao campo editorial, que é o que atinge a matéria literária mais de perto, e à situação do país mais próspero dos cinco, Angola, lembramos que a indústria livreira é disputada palmo a palmo por casas editoriais portuguesas e brasileiras. Também os livros didáticos, segmento importante do ramo, são normalmente importados de Portugal, filão pelo qual o mercado brasileiro também se mostra seduzido. Na base para o suprimento estrangeiro estão os argumentos acerca da deficitária infraestrutura no país: matéria-prima, energia, combustível, água. Enquanto os manuais do ensino primário e do primeiro ciclo do secundário são elaborados por profissionais angolanos e apenas produzidos em Portugal, o material didático dos últimos anos do ensino secundário (equivalente ao Ensino Médio) é escrito por agentes portugueses e apenas inspecionado pelo Ministério da Educação angolano, solução encontrada para driblar a falta de empresas e de técnicos qualificados.

A situação no ramo editorial, num sentido geral, não é mais confortável. A única editora de raiz angolana, a Nzila, tem majoritariamente capital luso, da Editorial Caminho, enquanto a Luanda Editora faz parte do grupo português Texto Editora. Além dessas, o mercado é ainda dominado pelas também portuguesas Porto Editora e Plátano. O secretário-geral adjunto da Brigada Jovem de Literatura, John Bella, afirma que a leitura de 
autores angolanos é escassa no próprio país, em parte porque não há uma política de incentivo à publicação dos autores nacionais (SANTOS, 2011).

Uma primeira questão que ressalta diante desse panorama é: como falar da construção de identidades nacionais num cenário em que mesmo o material didático utilizado nas escolas traduz uma ideologia que não lhes é própria e, pior que isso, ainda é veiculada por meio do antigo agente colonizador? A situação torna-se mais complexa se considerarmos o drama linguístico. Ainda que o português seja a língua oficial do país, os livros formulados por portugueses e impressos em Portugal muito provavelmente não atendem à diversidade linguística do país, que conta com inúmeros dialetos, dentre os quais os mais significativos, o umbundu e o kimbundu, que representam a grande maioria da população. Num panorama em que a manutenção da língua dentro da CPLP (Comunidade dos Países de Língua Portuguesa) tem um peso não só político, mas comercial, como já visto, não se verifica grande interesse nessa inclusão ou num provável esfacelamento linguístico do português.

Em suma, o que normalmente entendemos por africanidade e mais especificamente como identidades nacionais dos países africanos, em particular as de língua portuguesa, aparenta ser uma construção que, de fato, conta com poucas ferramentas. Lembremos, por exemplo, de Benedict Anderson (2008), para quem as construções identitárias do século XIX foram tributárias sobretudo da imprensa e da literatura. É certo que hoje dispomos de muitos outros canais de mediação, mas nem por isso aqueles perderam seu sentido. Carecendo de uma competente estrutura interna de construção e fixação identitária e enfrentando conflitos vários para administrar a diversidade cultural a partir do exercício político, fica de certa forma patente que as imagens identitárias dos países africanos com que trabalhamos são mais o fruto de uma perspectiva criada internacionalmente que propriamente de uma política interna.

Num momento em que a literatura africana nos chega com grande facilidade, veiculada pelas principais editoras brasileiras, cabe-nos perguntar até que ponto não endossamos uma representação desse espaço fundada em imagens reapropriadas e devolvidas através de lugares-comuns e, desse modo, não condenamos seus autores, já carentes de vias de escoamento, a uma escrita monocórdica e engessada pela demanda editorial?

Talvez a própria literatura venha tentando dar resposta a essa questão, enquanto expressa o dilema em que está posta. Caminhos distintos insinuam-se na produção de dois escritores que alcançaram grande repercussão no Brasil: Mia Couto e José Eduardo Agualusa. Contrariando, em parte, o que já foi defendido aqui acerca da tendência de homogeneizar experiências diversificadas, tomamos da extensa obra desses dois autores para ler aí uma metáfora de um certo mal-estar perante as condições de produção do artista e do lugar da cultura letrada nesses contextos. Tais 
considerações, contudo, não pretendem esgotar o sentido daqueles textos que, por si só, demandam um tratamento muito mais aprofundado para concluir qualquer análise que seja.

\section{As terras do fim do mundo e o exílio na língua}

Ligados pela amizade, o moçambicano Mia Couto e o angolano José Eduardo Agualusa também afirmam compartilhar uma tradição dentro da literatura de língua portuguesa. Mia Couto alega ter descoberto através da leitura do angolano Luandino Vieira a possibilidade de driblar a rigidez do idioma para criar uma escrita singular, que, por sua vez, havia se deslumbrado com a descoberta de Guimarães Rosa durante o período em que esteve preso no Tarrafal, Cabo Verde, pelo regime colonial. Agualusa, como ele mesmo se insere, completaria essa cadeia literária. Apesar da aproximação entre eles, as imagens com que cada um exprimiu e exprime a condição africana diante de uma cultura em língua portuguesa parece revelar diferenças latentes. Enquanto a escrita de Mia Couto tende a um escapismo tópico, Agualusa perscruta uma possível unidade em meio ao do amálgama linguístico.

O primeiro romance de Mia Couto, Terra sonâmbula (1992), elege como cenário principal um ônibus incendiado em meio à estrada no decurso da guerra civil pós-independência em nação africana. A escolha emblemática de uma estrada esquecida, mas ainda assim perigosa para os refugiados do enredo, o velho Tuahir e o menino Muidinga, aponta metaforicamente para esse entrelugar, suspenso no tempo e no espaço, a impossibilitar tanto o avanço como o recuo. A única solução era a de manterem-se ali escondidos, camuflados pelos cadáveres do incineramento do ônibus. A desolação já se anuncia na abertura:

Naquele lugar, a guerra tinha morto a estrada. Pelos caminhos só as hienas se arrastavam, focinhando entre cinzas e poeiras. A paisagem se mestiçara de tristezas nunca vistas, em cores que se pegavam à boca. Eram cores suas, tão sujas que tinham perdido toda a leveza, esquecidas da ousadia de levantar asas pelo azul. Aqui, o céu se tornara impossível. E os viventes se acostumaram ao chão, em resignada aprendizagem da morte. (COUTO, 2007, p. 9).

Permanecer no ônibus representa a opção pelo alheamento e pelo esquecimento em relação à realidade. Diante da estupefação do menino, o velho Tuahir justifica: “- Você não sabe nada, miúdo. O que já está queimado não volta a arder” (COUTO, 2007, p. 10). Junto a um dos cadáveres, a de um jovem rapaz, encontram uma mala que contém os diários de Tuahir, uma história de vida que os religa à vida através da função da memória. 
Despojos da guerra, rastros de identidade: Alguns dilemas da literatura africana de expressão ...

Após um presente fundado na escatologia, uma nova cosmogonia poderá ter lugar, segundo as palavras do feiticeiro:

As mulheres mastigarão areia e serão tantas e tão esfaimadas que um buraco imenso tornará a terra oca e desventrada. No final, porém, restará uma manhã como esta, cheia de luz nova e se escutará uma voz longínqua como se fosse uma memória de antes de sermos gente. E surgirão os doces acordes de uma canção, o terno embalo da primeira mãe. Esse canto, sim, será nosso, a lembrança de uma raiz profunda que não foram capazes de nos arrancar. Essa voz nos dará a força de um novo princípio e, ao escutá-la, os cadáveres sossegarão nas covas e os sobreviventes abraçarão a vida com o ingénuo entusiasmo dos namorados. (COUTO, 2007, p. 202).

A varanda do frangipani (2005), seu segundo romance, aborda, por meio de enredo meio policialesco, os embates entre as antigas tradições e o espaço urbano pós-colonial. Desse conflito, destaca-se um desejo profundo de entranhamento, ou seja, esse internamento dos personagens nos tempos e nos espaços da origem, de uma forma quase obsessiva.

Uma estranha morte atrai para a antiga fortaleza colonial, em que funciona um asilo de velhos, o inspetor de polícia, Izidine Naíta. Os métodos e a formação de Izidine contrastam com a sabedoria milenar. Enquanto ele procura uma causalidade lógica, os anciãos justificam o possível assassinato de Vasto Excelência, diretor da instituição, com base em razões religiosas. Ao lado dos idosos está Marta, que atua como enfermeira, mas também como ardente defensora dos antigos costumes, personificados pelo frangipani, uma árvore frondosa em meio ao pátio da fortaleza.

Na linhagem de Brás Cubas, a história é narrada por Ermelindo Mucanga, um cadáver na abertura do romance, que reclama um enterro conforme as tradições do seu povo e que, por isso, ainda não encontrou descanso. A solução sugerida para o liberar da vida de xipoco é dada pelo halakavuma: ele deve morrer novamente. Para tanto, precisa encarnar um corpo próximo à morte, nesse caso, o do inspetor Izidine.

Apaixonado por Marta, Izidine vai se dando conta da impossibilidade de decifrar uma morte que não legou sequer um cadáver e cujos relatos só evidenciam contradições e prodígios por parte dos narradores. O cenário mesmo parece se perder no horizonte do mundo. É como uma ilha, na medida em que a presença de minas pelas estradas inviabilizam as comunicações. Ninguém entra, ninguém sai, a não ser por meio de helicóptero. Além do mais, uma antiga fortaleza nos confins do país, habitada por idosos, não chega a atrair a cobiça alheia. A perspectiva de Xidimingo, um dos internos do asilo, parece comungar com os demais, ainda que por diferentes razões: "O Moçambique que amei está morrendo. Nunca mais voltará. Resta-me só este espaçozito em que me sombreio de mar. Minha nação é uma varanda.” (COUTO, 2007, p. 47). 
O mais recente romance de Mia Couto, Jesusalém (2009), com título modificado na edição brasileira para Antes do nascer do mundo, retoma o tópico do insulamento através de personagens que compõem uma comunidade rarefeita, distante da cidade e de seus influxos, nos confins de um país. Dessa vez, ela é formada por cinco homens que se identificam por vínculos familiares mas cujo passado encobre relações conflituosas. O patriarca, Mateus Ventura, rebatizado na nova comunidade por Silvestre Vitalício, educa seus dois filhos, Ntunzi e Mwanito, o narrador, de modo a não cultivarem qualquer vestígios da memória, sejam eles narrativas, canções ou sonhos. Os poucos membros vivem seus dias vazios em companhia de um imenso silêncio. Forma ainda o grupo o tio Aproximado, responsável por abastecer os demais com os mantimentos da cidade, e Zacaria Kalash, espécie de pajem dos rapazes e serviçal do grupo, que, assim como o tio, habita uma edificação diferente do núcleo familiar.

Jesusalém, antigo posto militar durante a guerra colonial, perdeu sua importância e jaz esquecida da população. É ali que Silvestre pretende reiniciar o mundo, longe da corrupção moral que vigora na cidade, onde sua esposa Dordalma perdeu-se dos caminhos de uma vida em família. Jesusalém é um gesto de fundação; fundação que se apoia mais na ausência do que propriamente na tessitura de símbolos representativos: "Era isso Jesusalém: não um lugar mas a espera de um Deus que ainda estivesse por nascer." (COUTO, 2009, p. 276).

Na apresentação de Antes de nascer o mundo, realizada pela Livraria Cultura, em junho de 2009, Mia Couto tenta descrever a metáfora posta no romance em relação a Moçambique e aos moçambicanos: "O nosso lugar sempre foi onde os outros nos pensaram. Não fomos senhores do que fizemos senão na ficção", como que a apontar o cerco formado em torno das culturas africanas, retirando-lhes as próprias vozes e condenando-as a representarem os mesmos papéis. Nesse labirinto, confirma Mia Couto, em que o peso do passado faz-se insuportável e torna a vida estanque, em que se perdeu a habilidade de dominar a própria existência, a única saída encontrada é a de criar uma nova vida, mas que, a curto prazo, também se mostra insatisfatória.

O encantamento abandonou a realidade, daí essa busca alucinada em direção a um epicentro perdido nos confins do mundo, que se repete em vários romances. Também o angolano José Eduardo Agualusa representa em sua obra um extravasamento da realidade do seu país, mas, em lugar da criação de um axis mundi, o exílio converte-se na própria língua.

Após os dois primeiros romances, ambientados em Angola, mas com fortes motivações históricas (A conjura, de 1989, e Estação das chuvas, de 1996), Agualusa retoma em seu terceiro romance, Nação crioula (1997), a acalentada criação de Eça de Queirós, Fradique Mendes, e religa as histórias portuguesa, africana e brasileira no final do séc. XIX. 
Despojos da guerra, rastros de identidade: Alguns dilemas da literatura africana de expressão ...

O próprio título aponta para essa condição mestiça e estigmatizada das culturas atlânticas de língua portuguesa. Organizado entre Luanda, Paris, Olinda e Rio de Janeiro, o enredo do romance aborda a intricada rede da escravatura africana por meio da paixão amorosa entre Fradique e Ana Olímpia Vaz de Caminha, antiga escrava que se tornou uma das grandes fortunas de Angola.

O tom jocoso de Fradique cede espaço a uma busca frenética em Um estranho em Goa (2000). Em parte, ambientado nos mais ermos lugares da língua portuguesa, o livro é resultado de uma bolsa concedida ao autor pela Fundação Oriente graças à qual visitou Goa. Nele fundem-se a história de Angola e a comunidade goesa de língua portuguesa, contando ainda com uma incursão pelo Brasil.

O narrador, o jornalista José Eduardo, espécie de alter ego de Agualusa, segue as pistas de um condecorado herói da independência angolana, António Plácido Domingo, que abandonara as fileiras lusitanas durante a guerra colonial e aderira à causa africana. Encontrado em Goa, o narrador desvenda que a história ufanista encobre outros interesses e uma trama policialesca e mística cruza os rumos do resgate da história angolana. A ambiência criada é propícia para abordar a intricada questão identitária goesa a partir do olhar de um estrangeiro. Como no caso angolano, não há padrões definidos, apenas culturas diversas que se imbricam ocasionando um contínuo tensionamento. A retomada da viagem iniciática de Vasco da Gama, recriada n'Os Lusíadas, não encontra mais na Índia um porto seguro; a bagagem do viajante comporta, no presente, apenas as lembranças do passado glorioso.

Após privilegiar mais uma vez o espaço brasileiro em $O$ ano que Zumbi tomou o Rio (2003), Agualusa publica a história da melancólica vida de Félix Ventura, em $O$ vendedor de passados (2004). Através do olhar da lagartixa que habita as paredes da biblioteca da casa, entramos em contato com Ventura, um albino, que ganha a vida a compor passados (árvores genealógicas), em geral, para a emergente classe angolana do pós-guerra até que um dia certo freguês propõe-lhe algo mais sério: criar efetivamente uma nova vida através da escrita. O livro constrói-se, assim, sobre essa metáfora de como a inscrição pode fabricar destinos, unir e separar pessoas e povos. A escrita faz-se no romance o espaço por excelência de poder e de reconhecimento; de forma análoga, o próprio autor vale-se da língua para urdir o seu mundo e seu sustento:

Partilho com Félix Ventura um amor (no meu caso sem esperança) pelas palavras antigas. A Félix Ventura quem o educou neste sentimento foi, primeiro, o pai, Fausto Bendito, e a seguir um velho professor, dos primeiros anos do liceu, sujeito de modos melancólicos, alto, e de tal forma delgado que parecia caminhar sempre de perfil, como uma gravata egípcia. Gaspar, assim se chamava o professor, comovia-se com o desamparo de certos vocábulos. Dava com eles abandonados à sua sorte, nalgum 
lugar ermo da língua, e procurava resgatá-los. Usava-os com ostentação e persistência, o que consternava uns e desconcertava outros. Creio que triunfou. Os seus alunos começaram por utilizar esses vocábulos, primeiro por troça, e a seguir como uma gíria íntima, uma tatuagem tribal, que os fazia distintos da restante juventude. Hoje, assegurou-me Félix, são ainda capazes de se reconhecerem uns aos outros, mesmo quando nunca se viram antes, às primeiras palavras. (AGUALUSA, 2004, p. 26).

O seu último romance, Milagrário pessoal (2010), pode ser entrevisto como o corolário dessa experiência intensamente lusófona, uma ode à língua portuguesa e às suas mais variadas expressões pelo mundo. Unidos por esse amor à palavra, uma jovem linguista portuguesa e um velho professor angolano, que funciona como narrador, dedicam-se à recolha encantada de neologismos do português enquanto revisitam os espaços em que a língua circula, através do estratagema de narrativas encaixadas. O subtítulo, "apologia das varandas, dos quintais e da língua portuguesa, seguida de uma breve refutação da morte", alude aos espaços em que a língua, por meio de contatos multiculturais, atingiu sua melhor expressão.

Tendo estabelecido residência em vários países a partir de 1998, entre os quais Portugal e Brasil, onde fundou uma editora, a Língua Geral, Agualusa exerce, no papel que ele mesmo criou, uma espécie de embaixada da língua portuguesa. Além de escritor e editor, a função de leitor fica patente na sua obra. Desde a reverência ao Eça do Fradique Mendes, a Camões e a Pessoa, enquanto alicerces da língua, revelam-se variadas referências a autores universais, como Baudelaire, Oscar Wilde, Borges, Hemingway, como também a cultores e pensadores da língua portuguesa: Basílio da Gama, Gonçalves Dias, Camilo Pessanha, Machado de Assis, Cruz e Sousa, Jorge Amado, Ferreira Gullar, Manoel de Barros, Caetano Veloso, Adriana Calcanhoto, dentre outros. A remissão a escritos literários, sejam eles portugueses, brasileiros ou africanos, parece servir, desse modo, como esteio à língua, característica bastante evidenciada também em Mia Couto.

O império colonial português que, paulatinamente, desfez-se, com D. Sebastião, com a independência brasileira, com a quimera do mapa cor-de-rosa e mais tarde com a guerra colonial, parece querer organizar-se mais uma vez, não no devaneio pessoano da Mensagem, mas na sintaxe de Agualusa, enquanto recusa dos laços colonialistas, mas ainda fundado numa unidade de identificação e já agora de resistência: a língua portuguesa.

Tanto Mia Couto como Agualusa, em boa parte de seus romances, compõem mundos que recusam de alguma forma o confrontamento com o momento presente e a realidade circundante de seus países. Mia Couto projeta um topos distante no espaço e no tempo como metáfora da "impossibilidade de viver se não for criando uma nova vida” (COUTO, 
Despojos da guerra, rastros de identidade: Alguns dilemas da literatura africana de expressão ...

25/06/2009). Agualusa constrói esse mesmo mundo numa terra também abstrata, fundada por uma língua e não mais por fronteiras geográficas. Em Mia Couto, nota-se o internamento de personagens; em Agualusa, evidencia-se a diluição deles num espaço transnacional. Em ambas as atitudes, pressente-se a dificuldade de expressar um mundo estabelecido dentro de suas fronteiras físicas.

Além dos dramas políticos e sociais, evidentemente correlatos, essa representação não deixa de indiciar a incômoda posição do escritor e da literatura nos países africanos de língua portuguesa. Com um número reduzido de leitores intramuros, editados quase que exclusivamente por editoras em Portugal e no Brasil, a literatura africana parece configurar-se mais como uma projeção externa do que uma construção interna.

E até que ponto a África não se tornou um receptáculo de imagens e de desejos exteriores a ela mesma? Nesse território do "outro", podemos consumir a ilusão de que o caos está distante de nós, no outro lado do Atlântico, e que problemas sociais muito aparentados àqueles lidos na ficção não rondam nossas portas diariamente. É como se, de alguma forma, tivéssemos transportado o nosso Nordeste do "romance de 30" para as terras africanas de hoje.

Mia Couto, não obstante o sucesso que granjeia internacionalmente, não abriu mão de sua atividade profissional como biólogo, o que, talvez, sinalize para a recusa de depender financeiramente da literatura ou da impossibilidade da profissionalização como escritor em solo tão precário. Já a opção de Agualusa parece ter sido a de brigar por essa profissionalização, ainda que às custas de que ela só se efetivasse além fronteiras e de que ele mesmo se tornasse um produtor dentro da cadeia editorial.

É talvez por essa palheta que possamos ler a escrita de Tiara e suas lacunas. Além do exercício de um romance que narra os anos de formação de sua protagonista, essa trajetória fala mais ainda pela ausência; a ausência de meios para que a literatura se constitua uma prática social. Fala ainda do desenraizamento, da necessidade de optar por uma vida além das fronteiras reconhecidas afetivamente, como condição de manter as vidas de África dentro de si mesma.

Se nós, os estrangeiros, insistimos em inventar e estampar uma África que componha nossos cartões-postais ou mesmo as nossas imagens de holocausto, os escritores, por seu turno, testemunham, pela via ficcional, muitos dos impasses da criação literária nos países africanos de língua portuguesa. 


\section{Referências}

AGUALUSA, José Eduardo. Nação crioula. Rio de Janeiro: Gryphus, 1998.

. Um estranho em Goa. Rio de Janeiro: Gryphus, 2010.

O vendedor de passados. Rio de Janeiro: Gryphus, 2004.

. Milagrário pessoal. Rio de Janeiro, Língua Geral, 2010.

ANDERSON, Benedict. Comunidades imaginadas: reflexões sobre a origem e a difusão do nacionalismo. São Paulo: Companhia das Letras, 2008.

COUTO, Hildo Honório; EMBALÓ, Filomena. Literatura, língua e cultura na Guiné-Bissau: um país da CPLP. Papia, n. 20, 2010. Disponível em: $<$ http://abecs.net/ojs/index.php/papia/article/viewFile/341/362 >. Acesso: 22 julho 2011.

COUTO, Mia. Terra sonâmbula. São Paulo: Companhia das Letras, 2007.

2007.

A varanda do frangipani. São Paulo: Companhia das Letras,

Antes de nascer o mundo. São Paulo: Companhia das Letras,

2009.

Apresentação do romance Antes de nascer o mundo. São Paulo, Livraria Cultura 2009. Disponível em: <http://www.youtube.com/ watch?v=MLq29FFC-2o\&feature=related > Acesso em: 12 agosto 2011.

EMBALÓ, Filomena. Tiara. Lisboa: Instituto Camões, 1999.

Breve resenha sobre a literatura da Guiné-Bissau (2004). Disponível em: <http://opatifundio.com/site/?p=2754>. Acesso em 12 maio 2011.

HALL, Stuart. Quem precisa de identidade? In: SILVA, Tomaz Tadeu da (Org.). Identidade e diferença: a perspectiva dos estudos culturais. 9.ed. Petrópolis, RJ: Vozes, 2009.

PESSOA, Fernando. O eu profundo e os outros eus. 14.ed. Rio de Janeiro: Nova Fronteira, 1980.

SANTOS, Seomara. Falta de apoios condiciona publicação de obras literárias. Disponível em: <http://www.ueangola.com/index.php/noticias/item/755-falta-de-apoios-condiciona-publica\%C3\%A7\%C3\%A3o-de-obras-liter\%C3\%A1rias.html>. Acesso em: 12 março 2011. 